\title{
Smokeless tobacco use as a risk factor for periodontal
} disease

\author{
Kavitha P. Kamath ${ }^{1}$, Supriya Mishra ${ }^{2}$ and Pradeep S. Anand ${ }^{3} *$ \\ 1 Department of Oral Pathology, People's Dental Academy, Bhopal, India \\ ${ }^{2}$ Department of Periodontics, Maitri College of Dentistry and Research Centre, Anjora, India \\ ${ }^{3}$ Department of Dentistry, ESIC Medical College Hospital, Parippally, India \\ ${ }^{*}$ Correspondence: deepusanand@yahoo.co.in \\ Edited by: \\ Alexandrina L. Dumitrescu, Dental Private Practice, Romania \\ Reviewed by: \\ Mine Tezal, University at Buffalo, State University of New York, USA \\ Peter N. Lee, P N Lee Statistics and Computing Ltd, UK
}

Keywords: tobacco, smokeless tobacco, periodontal disease, periodontal attachment loss, gingival recession

Periodontal disease is one of the leading causes of tooth loss, particularly among older individuals (1-6). Although dental plaque-associated microorganisms are the primary etiologic agents of periodontal diseases, several other factors such as local, genetic, systemic, and environmental factors play an important role in determining the susceptibility of individuals to periodontal diseases. Tobacco smoking is one of the most important environmental risk factors for periodontal diseases. Large numbers of studies have been conducted to understand the role of smoking in the etiology of periodontal diseases and the available data show that smoking is associated with increased prevalence and severity of periodontal disease, which may be due to the adverse effects of tobacco smoke on the physiology, immunology, and microbiology of the oral environment. Unlike smoking, the role of oral smokeless tobacco (SLT) in the etiology of periodontal disease has received considerably less attention.

Although traditionally, oral SLT consumption has been associated with oral malignant and potentially malignant lesions, emerging data suggest that these habits may be associated with poor periodontal health also. Besides some case reports mentioning periodontal changes associated with oral SLT habits (7), initial studies conducted in the US have shown that oral SLT habits are associated with increased incidence of gingival recession $(8-11)$. Studies conducted in Sweden also have shown that the consumption of moist snuff, an oral SLT product, is associated with increased prevalence of gingival recession (12-14). However, some studies conducted in the US and Sweden have failed to show any association between SLT habits and periodontal changes such as gingival recession, attachment loss, or bone loss (15-18). Unlike the studies among the Swedish and US populations, studies conducted among Asian populations have shown that oral SLT habits are associated with destructive periodontal disease. Studies conducted in India have reported that oral SLT users tend to have higher scores and risk for periodontal disease (1922). Similar results were reported among SLT users in Bangladesh and Thailand also $(23,24)$. A study based on National Health and Nutrition Examination Survey III data conducted in the US also showed strong association between oral SLT use and severe active periodontal disease (25).

Very few studies have reported on the pattern of periodontal destruction among oral SLT users. A study on the patterns of tooth loss among tobacco users in central India showed that mandibular tooth loss was more among oral SLT users suggesting that the deleterious effects of SLT use is manifested more in mandibular teeth (26). Studies reporting the occurrence of gingival recession among oral SLT users have reported that these occurred at sites adjacent to mucosal lesions suggesting that the recession was a result of long-term injury to the gingival tissues from the SLT product $(8,10,13,14)$. Oral SLT users in a central Indian population were shown to have an increase in prevalence and severity of recession and attachment loss at mandibular teeth, buccal surfaces, anterior teeth, and molars-the surfaces most likely to have prolonged exposure to SLT product due to retention of the SLT product at the mandibular buccal or anterior labial vestibule (21).

Oral SLT consumption in various forms is highly prevalent among all populations, particularly in the Asian countries (2735), and a wide variety of SLT products are available worldwide $(36,37)$. The most common SLT products available in the US include chewing tobacco and snuff (moist and dry), and in Sweden, the most common product is snus. In Asian countries, such as India and Bangladesh, a myriad of SLT products are available such as betel quid with tobacco, zarda (prepared by boiling tobacco leaves with water and slaked lime), gutka (mixture of powdered tobacco, areca nut, slaked lime, and catechu), mawa (areca nut, tobacco, and slaked lime), and khaini (tobacco with slaked lime).

Although oral SLT habits are common among all populations, strong associations between SLT habits and destructive periodontal disease has been observed mainly among Asian populations, whereas a systematic review of studies testing the association between SLT habits and periodontal disease conducted in Sweden and the US suggested that SLT habits may not be related to periodontal diseases (38). Such contradictory observations may be due to several factors such as differences in the trends of oral SLT practices and the type of SLT products used by the respective populations. 
While products such as the Swedish snus has been shown to be less harmful compared to smoking and other SLT products (39), oral SLT products available commercially in India and other Asian countries contain more than 4000 toxic ingredients, which can cause tissue injury on account of their mutagenic and carcinogenic properties $(40,41)$. These include alkaloids such as nicotine, tobaccospecific nitrosamines, phytosterols such as cholesterol, heterocyclic hydrocarbons, pesticides, alkali nitrites, radioactive substances, and toxic metals such as lead, cadmium, and arsenic (41). Moreover, among Asian populations, unlike smoking, which is almost exclusively confined to males, oral SLT consumption is highly prevalent among both males and females (32, 34, 42). The high prevalence of these habits may be due to a general misconception, particularly among Asian populations, that oral SLT habits are generally less harmful than smoking. While this may be true of certain products such as the Swedish snus, which is being recommended as a less harmful alternative to smoking (39, $43,44)$, the products available in the Asian countries have been shown to contain large quantities of chemicals, which are toxic to the human tissues $(40,41)$. Moreover, such habits are culturally ingrained among these populations, which consider SLT products as relatively acceptable forms of tobacco consumption when compared to smoking, and individuals, considering it as a part of their life style, are introduced to such habits at a very young age (32, 45, 46). Lower levels of education, poor socioeconomic status, and rural areas of residence have also been identified as factors associated with oral SLT consumption $(31,32,42,47,48)$. Studies on tobaccocessation behavior have shown that oral SLT users are less likely to attempt quitting the habit compared to smokers in spite of an awareness of the harmful effects of such habits $(49,50)$. On account of these variations in the products and patterns of SLT consumption, comparison between observations from Asian populations and those from European and US populations becomes difficult.

Another factor that needs to be considered while assessing the strength of association between SLT and periodontal disease is the fact that the SLT products used in Asian countries, where a stronger evidence of association is found, contains a wide variety of ingredients besides tobacco such as betel quid, areca nut, slaked lime, catechu, spices, etc. Moreover, the methods of preparation of these products also vary, which may contribute to alteration of toxicity of these ingredients. Hence, it may be difficult to identify the specific effects of tobacco on the periodontal tissues. Furthermore, the effects of these different commercial products on the periodontal tissues may also be different on account of their different chemical composition. To the best of our knowledge, no product-specific data regarding the effect of SLT on periodontal health among Indian or other Asian populations is available.

Nicotine, the principal alkaloid in tobacco, exerts a wide range of effects on the immune system and wound healing, which may play an important role in periodontal tissue destruction (51). Nicotine exposure has been shown to result in vasoconstriction $(52,53)$ and impaired angiogenesis $(54,55)$. Its effects on neutrophil function include increased shedding of adhesion molecules (56) and alteration of f-actin kinetics (57), resulting in reduced migration of neutrophils into the oral tissues (58), and inhibition of phagocytosis and oxidative killing $(59,60)$. Nicotine exposure also results in reduced proliferation and function of T-lymphocytes (61), decreased phagocytosis and production of pro-inflammatory cytokines and oxygen radicals by monocytes $(59,62)$, increased levels of tissue-destructive cytokine such as TNF- $\alpha$ (63), reduction in levels of antibodies to periodontal pathogens (64-67), and impaired attachment of human periodontal ligament fibroblasts (68).

Absorption of nicotine from SLT products occurs through the oral mucosa and absorption is higher from products, which have a higher $\mathrm{pH}(41,69,70)$. SLT products from different countries differ in their values of $\mathrm{pH}$, total nicotine, and unionized nicotine, with products available in southeast Asian countries having higher levels of these parameters (37). On account of these differences, there are considerable limitations in drawing broad conclusions on the impact of SLT products on public health.

Nevertheless, considering the health hazards posed by oral SLT habits, par- ticularly among Asian populations, and the high prevalence of such habits among both males and females, lack of willingness among SLT users to quit the habit is alarming, particularly since nicotine dependence and withdrawal symptoms have been shown to be higher among oral SLT users than smokers (71). In the context of such widespread use of SLT products, the implications of the effects of such habits on periodontal and oral health and on oral healthrelated quality of life cannot be ignored. In populations, where the tobacco consumption in the form of oral SLT products is predominant compared to smoking, the role of oral SLT products on periodontal health should be considered in the etiology of periodontal diseases. The possible role of oral SLT habits in the etiology of periodontal disease among these populations has important implications not only for future research but also for design of public health programs as well as for periodontal treatment planning.

Further studies need to be carried out in high-risk populations with improved methodology and incorporating additional parameters such as type of SLT product used, alveolar bone level, and microbial factors to better understand the relationship between oral SLT habits and periodontal diseases. Knowledge generated from such research endeavors can be combined with the data generated from epidemiologic studies regarding factors contributing to the initiation and maintenance of oral SLT habits so as to design public health programs for tackling the burden of SLT habits. SLT-cessation programs in dental settings have been shown to be effective in increasing the proportion of oral SLT users who quit the habit $(72,73)$. Hence, tobacco-cessation programs in a dental setting should also include smokeless forms. Once such modifications are successfully implemented, the periodontist can play a greater role in tackling this social menace of SLT consumption, thereby contributing to a reduction in the economic burden arising from these habits as well as an improvement of oral and general health and related quality of life.

\section{REFERENCES}

1. Reich E, Hiller KA. Reasons for tooth extraction in the western states of Germany. Community Dent Oral Epidemiol (1993) 21:379-83. doi:10.1111/j. 1600-0528.1993.tb01103.x 
2. Angelillo IF, Nobile CG, Pavia M. Survey of reasons for extraction of permanent teeth in Italy. Community Dent Oral Epidemiol (1996) 24:336-40. doi:10.1111/j.1600-0528.1996.tb00872.x

3. Murray H, Locker D, Kay EJ. Patterns of and reasons for tooth extractions in general dental practice in Ontario, Canada. Community Dent Oral Epidemiol (1996) 24:196-200. doi:10.1111/j.16000528.1996.tb00841.x

4. Ong G, Yeo JF, Bhole S. A survey of reasons for extraction of permanent teeth in Singapore. Community Dent Oral Epidemiol (1996) 24:124-7. doi:10.1111/j.1600-0528.1996.tb00828.x

5. Anand PS, Kuriakose S. Causes and patterns of loss of permanent teeth among patients attending a dental teaching institution in south India. J Contemp Dent Pract (2009) 10:E057-064.

6. Anand PS, Kamath KP, Nair B. Trends in extraction of permanent teeth in private dental practices in Kerala state, India. J Contemp Dent Pract (2010) 11:41-8.

7. Weintraub JA, Burt BA. Periodontal effects and dental caries associated with smokeless tobacco use. Public Health Rep (1987) 102:30-5.

8. Poulson TC, Lindenmuth JE, Greer RO Jr. A comparison of the use of smokeless tobacco in rural and urban teenagers. CA Cancer J Clin (1984) 34:248-61. doi:10.3322/canjclin.34.5.248

9. Offenbacher S, Weathers DR. Effects of smokeless tobacco on the periodontal, mucosal and caries status of adolescent males. J Oral Pathol (1985) 14:169-81. doi:10.1111/j.1600-0714.1985. tb00480.x

10. Robertson PB, Walsh M, Greene J, Ernster V, Grady D, Hauck W. Periodontal effects associated with the use of smokeless tobacco. J Periodontol (1990) 61:438-43. doi:10.1902/jop.1990.61.7.438

11. Beck JD, Koch GG, Offenbacher S. Incidence of attachment loss over 3 years in older adults - new and progressing lesions. Community Dent Oral Epidemiol (1995) 23:291-6. doi:10.1111/j.16000528.1995.tb00251.x

12. Andersson G, Axell T. Clinical appearance of lesions associated with the use of loose and portion-bag packed Swedish moist snuff: a comparative study. J Oral Pathol Med (1989) 18:2-7. doi:10.1111/j.1600-0714.1989.tb01349.x

13. Rolandsson M, Hellqvist L, Lindqvist L, Hugoson A. Effects of snuff on the oral health status of adolescent males: a comparative study. Oral Health Prev Dent (2005) 3:77-85.

14. Monten U, Wennstrom JL, Ramberg P. Periodontal conditions in male adolescents using smokeless tobacco (moist snuff). J Clin Periodontol (2006) 33:863-8. doi:10.1111/j.1600-051X.2006.01005.x

15. Wolfe MD, Carlos JP. Oral health effects of smokeless tobacco use in Navajo Indian adolescents. Community Dent Oral Epidemiol (1987) 15:230-5. doi:10.1111/j.1600-0528.1987.tb00527.x

16. Wickholm S, Soder PO, Galanti MR, Soder B, Klinge B. Periodontal disease in a group of Swedish adult snuff and cigarette users. Acta Odontol Scand (2004) 62:333-8. doi:10.1080/ 00016350410001801

17. Bergstrom J, Keilani H, Lundholm C, Radestad U. Smokeless tobacco (snuff) use and periodontal bone loss. J Clin Periodontol (2006) 33:549-54. doi:10.1111/j.1600-051X.2006.00945.x
18. Hugoson A, Rolandsson M. Periodontal disease in relation to smoking and the use of Swedish snus: epidemiological studies covering 20 years (1983-2003). J Clin Periodontol (2011) 38:809-16. doi:10.1111/j.1600-051X.2011.01749.x

19. Parmar G, Sangwan P, Vashi P, Kulkarni P, Kumar S. Effect of chewing a mixture of areca nut and tobacco on periodontal tissues and oral hygiene status. J Oral Sci (2008) 50:57-62. doi:10.2334/ josnusd.50.57

20. Sumanth S, Bhat KM, Bhat GS. Periodontal health status in pan chewers with or without the use of tobacco. Oral Health Prev Dent (2008) 6:223-9.

21. Anand PS, Kamath KP, Bansal A, Dwivedi S, Anil S. Comparison of periodontal destruction patterns among patients with and without the habit of smokeless tobacco use - a retrospective study. J Periodontal Res (2013) 48:623-31. doi:10.1111/ jre. 12048

22. Mohamed S, Janakiram C. Periodontal status among tobacco users in Karnataka, India. Indian J Public Health (2013) 57:105-8. doi:10.4103/ 0019-557x.115006

23. Chatrchaiwiwatana S. Dental caries and periodontitis associated with betel quid chewing: analysis of two data sets. J Med Assoc Thai (2006) 89:1004-11.

24. Akhter R, Hassan NM, Aida J, Takinami S, Morita M. Relationship between betel quid additives and established periodontitis among Bangladeshi subjects. J Clin Periodontol (2008) 35:9-15. doi:10. 1111/j.1600-051X.2007.01164.x

25. Fisher MA, Taylor GW, Tilashalski KR. Smokeless tobacco and severe active periodontal disease, NHANES III. J Dent Res (2005) 84:705-10. doi:10.1177/154405910508400804

26. Anand PS, Kamath KP, Shekar BR, Anil S. Relationship of smoking and smokeless tobacco use to tooth loss in a central Indian population. Oral Health Prev Dent (2012) 10:243-52.

27. Nelson DE, Tomar SL, Mowery P, Siegel PZ. Trends in smokeless tobacco use among men in four states, 1988 through 1993. Am J Public Health (1996) 86:1300-3. doi:10.2105/AJPH.86.9.1300

28. Sreeramareddy CT, Ramakrishnareddy N, Harsha Kumar H, Sathian B, Arokiasamy JT. Prevalence, distribution and correlates of tobacco smoking and chewing in Nepal: a secondary data analysis of Nepal demographic and health survey-2006. Subst Abuse Treat Prev Policy (2011) 6:33. doi:10.1186/ 1747-597x-6-33

29. Giovino GA, Mirza SA, Samet JM, Gupta PC, Jarvis MJ, Bhala N, et al. Tobacco use in 3 billion individuals from 16 countries: an analysis of nationally representative cross-sectional household surveys. Lancet (2012) 380:668-79. doi:10. 1016/s0140-6736(12)61085-x

30. Palipudi KM, Gupta PC, Sinha DN, Andes LJ, Asma S, Mcafee T. Social determinants of health and tobacco use in thirteen low and middle income countries: evidence from global adult tobacco survey. PLoS One (2012) 7:e33466. doi:10.1371/ journal.pone.0033466

31. Prabhakar B, Narake SS, Pednekar MS. Social disparities in tobacco use in India: the roles of occupation, education and gender. Indian J Cancer (2012) 49:401-9. doi:10.4103/0019-509x.107747

32. Sinha DN, Gupta PC, Ray C, Singh PK. Prevalence of smokeless tobacco use among adults in WHO
South-East Asia. Indian J Cancer (2012) 49:342-6. doi:10.4103/0019-509x.107726

33. Usmanova G, Neumark Y, Baras M, Mckee M. Patterns of adult tobacco use in Uzbekistan. Eur J Public Health (2012) 22:704-7. doi:10.1093/eurpub/ ckr 125

34. Bhawna G. Burden of smoked and smokeless tobacco consumption in India - results from the global adult tobacco survey India (GATSIndia)- 2009-201. Asian Pac J Cancer Prev (2013) 14:3323-9. doi:10.7314/APJCP.2013.14.5.3323

35. Agaku IT, Ayo-Yusuf OA, Vardavas CI, Connolly G. Predictors and patterns of cigarette and smokeless tobacco use among adolescents in 32 countries, 2007-2011. J Adolesc Health (2014) 54:47-53. doi:10.1016/j.jadohealth.2013.07.037

36. Piano MR, Benowitz NL, Fitzgerald GA, Corbridge S, Heath J, Hahn E, et al. Impact of smokeless tobacco products on cardiovascular disease: implications for policy, prevention, and treatment: a policy statement from the American heart association. Circulation (2010) 122:1520-44. doi:10.1161/CIR. 0b013e3181f432c3

37. Stanfill SB, Connolly GN, Zhang L, Jia LT, Henningfield JE, Richter P, et al. Global surveillance of oral tobacco products: total nicotine, unionised nicotine and tobacco-specific $\mathrm{N}$-nitrosamines. Tob Control (2010) 20(3):e2. doi:10.1136/tc.2010. 037465

38. Kallischnigg G, Weitkunat R, Lee PN. Systematic review of the relation between smokeless tobacco and non-neoplastic oral diseases in Europe and the United States. BMC Oral Health (2008) 8:13. doi:10.1186/1472-6831-8-13

39. Lee PN. Epidemiological evidence relating snus to health - an updated review based on recent publications. Harm Reduct J (2013) 10:36. doi:10.1186/ 1477-7517-10-36

40. Nair U, Bartsch H, Nair J. Alert for an epidemic of oral cancer due to use of the betel quid substitutes gutkha and pan masala: a review of agents and causative mechanisms. Mutagenesis (2004) 19:251-62. doi:10.1093/mutage/geh036

41. Bhisey RA. Chemistry and toxicology of smokeless tobacco. Indian J Cancer (2012) 49:364-72. doi:10.4103/0019-509x.107735

42. Centers for Disease Control and Prevention. Differences by sex in tobacco use and awareness of tobacco marketing - Bangladesh, Thailand, and Uruguay, 2009. MMWR Morb Mortal Wkly Rep (2010) 59:613-8.

43. Ramstrom LM, Foulds J. Role of snus in initiation and cessation of tobacco smoking in Sweden. Tob Control (2006) 15:210-4. doi:10.1136/tc.2005. 014969

44. Rodu B, Phillips CV. Switching to smokeless tobacco as a smoking cessation method: evidence from the 2000 national health interview survey. Harm Reduct J (2008) 5:18. doi:10.1186/14777517-5-18

45. Sinha DN, Gupta PC, Pednekar M. Tobacco use among students in Bihar (India). Indian J Public Health (2004) 48:111-7.

46. Sinha DN, Gupta PC. Tobacco use among students in Orissa and Uttar Pradesh. Indian Pediatr (2005) 42:846-7.

47. Rooban T, Joshua E, Rao UK, Ranganathan K. Prevalence and correlates of tobacco use among 
urban adult men in India: a comparison of slum dwellers vs non-slum dwellers. Indian J Dent Res (2012) 23:31-8. doi:10.4103/0970-9290.99034

48. Thakur JS, Prinja S, Bhatnagar N, Rana S, Sinha DN. Socioeconomic inequality in the prevalence of smoking and smokeless tobacco use in India. Asian Pac J Cancer Prev (2013) 14:6965-9. doi:10. 7314/APJCP.2013.14.11.6965

49. Raute LJ, Sansone G, Pednekar MS, Fong GT, Gupta PC, Quah AC, et al. Knowledge of health effects and intentions to quit among smokeless tobacco users in India: findings from the international tobacco control policy evaluation (ITC) India pilot survey. Asian Pac J Cancer Prev (2011) 12:1233-8.

50. Sarkar BK, Arora M, Gupta VK, Reddy KS. Determinants of tobacco cessation behaviour among smokers and smokeless tobacco users in the states of Gujarat and Andhra Pradesh, India. Asian Pac J Cancer Prev (2013) 14:1931-5. doi:10.7314/ APJCP.2013.14.3.1931

51. Zee KY. Smoking and periodontal disease. Aust Dent J (2009) 54(Suppl 1):S44-50. doi:10.1111/j. 1834-7819.2009.01142.x

52. Bergstrom J, Bostrom L. Tobacco smoking and periodontal hemorrhagic responsiveness. J Clin Periodontol (2001) 28:680-5. doi:10.1034/j.1600051x.2001.028007680.x

53. Black CE, Huang N, Neligan PC, Levine RH, Lipa JE, Lintlop S, et al. Effect of nicotine on vasoconstrictor and vasodilator responses in human skin vasculature. Am J Physiol Regul Integr Comp Physiol (2001) 281:R1097-104.

54. Rezavandi K, Palmer RM, Odell EW, Scott DA, Wilson RF. Expression of ICAM-1 and E-selectin in gingival tissues of smokers and non-smokers with periodontitis. J Oral Pathol Med (2002) 31:59-64. doi:10.1046/j.0904-2512.2001.joptest.doc.x

55. Konishi $\mathrm{H}$, Wu J, Cooke JP. Chronic exposure to nicotine impairs cholinergic angiogenesis. Vasc Med (2010) 15:47-54. doi:10.1177/ 1358863 X09106326

56. Ryder MI, Fujitaki R, Lebus S, Mahboub M, Faia B, Muhaimin D, et al. Alterations of neutrophil Lselectin and CD18 expression by tobacco smoke: implications for periodontal diseases. J Periodontal Res (1998) 33:359-68. doi:10.1111/j.1600-0765. 1998.tb02211.x

57. Ryder MI, Wu TC, Kallaos SS, Hyun W. Alterations of neutrophil f-actin kinetics by tobacco smoke: implications for periodontal diseases. J Periodontal Res (2002) 37:286-92. doi:10.1034/j.1600-0765. 2002.01034.x
58. Pauletto NC, Liede K, Nieminen A, Larjava $\mathrm{H}$, Uitto VJ. Effect of cigarette smoking on oral elastase activity in adult periodontitis patients. J Periodontol (2000) 71:58-62. doi:10.1902/jop. 2000.71.1.58

59. Pabst MJ, Pabst KM, Collier JA, Coleman TC, Lemons-Prince ML, Godat MS, et al. Inhibition of neutrophil and monocyte defensive functions by nicotine. J Periodontol (1995) 66:1047-55. doi:10. 1902/jop.1995.66.12.1047

60. Xu M, Scott JE, Liu K-Z, Bishop HR, Renaud DE, Palmer RM, et al. The influence of nicotine on granulocytic differentiation - inhibition of the oxidative burst and bacterial killing and increased matrix metalloproteinase-9 release. BMC Cell Biol (2008) 9:19. doi:10.1186/1471-2121-9-19

61. Kalra R, Singh SP, Pena-Philippides JC, Langley RJ, Razani-Boroujerdi S, Sopori ML. Immunosuppressive and anti-inflammatory effects of nicotine administered by patch in an animal model. Clin Diagn Lab Immunol (2004) 11:563-8. doi:10.1128/ cdli.11.3.563-568.2004

62. Nouri-Shirazi M, Guinet E. Evidence for the immunosuppressive role of nicotine on human dendritic cell functions. Immunology (2003) 109:365-73. doi:10.1046/j.1365-2567.2003. 01655.x

63. Bostrom L, Linder LE, Bergstrom J. Clinical expression of TNF-alpha in smokingassociated periodontal disease. J Clin Periodonto (1998) 25:767-73. doi:10.1111/j.1600-051X.1998. tb02368.x

64. Quinn SM, Zhang JB, Gunsolley JC, Schenkein JG, Schenkein HA, Tew JG. Influence of smoking and race on immunoglobulin $\mathrm{G}$ subclass concentrations in early-onset periodontitis patients. Infect Immun (1996) 64:2500-5.

65. Tangada SD, Califano JV, Nakashima K, Quinn SM, Zhang JB, Gunsolley JC, et al. The effect of smoking on serum IgG2 reactive with Actinobacillus actinomycetemcomitans in early-onset periodontitis patients. J Periodontol (1997) 68:842-50. doi:10. 1902/jop.1997.68.9.842

66. Quinn SM, Zhang JB, Gunsolley JC, Schenkein HA, Tew JG. The influence of smoking and race on adult periodontitis and serum IgG2 levels. J Periodontol (1998) 69:171-7. doi:10.1902/jop.1998.69.2.171

67. Graswinckel JE, Van Der Velden U, Van Winkelhoff AJ, Hoek FJ, Loos BG. Plasma antibody levels in periodontitis patients and controls. J Clin Periodontol (2004) 31:562-8. doi:10.1111/j.1600051X.2004.00522.x
68. Gamal AY, Bayomy MM. Effect of cigarette smoking on human PDL fibroblasts attachment to periodontally involved root surfaces in vitro. $\mathrm{J} \mathrm{Clin}$ Periodontol (2002) 29:763-70. doi:10.1034/j.1600051X.2002.290814.x

69. Fant RV, Henningfield JE, Nelson RA, Pickworth WB. Pharmacokinetics and pharmacodynamics of moist snuff in humans. Tob Control (1999) 8:387-92. doi:10.1136/tc.8.4.387

70. Ayo-Yusuf O, Swart T, Pickworth W. Nicotine delivery capabilities of smokeless tobacco products and implications for control of tobacco dependence in South Africa. Tob Control (2004) 13:186-9. doi:10.1136/tc.2003.006601

71. Post A, Gilljam H, Rosendahl I, Bremberg S, Galanti MR. Symptoms of nicotine dependence in a cohort of Swedish youths: a comparison between smokers, smokeless tobacco users and dual tobacco users. Addiction (2010) 105:740-6. doi:10.1111/j.13600443.2009.02852.x

72. Severson HH, Eakin EG, Stevens VJ, Lichtenstein E. Dental office practices for tobacco users: independent practice and HMO clinics. Am J Public Health (1990) 80:1503-5. doi:10.2105/AJPH.80.12.1503

73. Gordon JS, Severson HH. Tobacco cessation through dental office settings. J Dent Educ (2001) 65:354-63.

Conflict of Interest Statement: The authors declare that the research was conducted in the absence of any commercial or financial relationships that could be construed as a potential conflict of interest.

Received: 19 August 2014; paper pending published: 05 September 2014; accepted: 30 September 2014; published online: 20 October 2014.

Citation: Kamath KP, Mishra $S$ and Anand PS (2014) Smokeless tobacco use as a risk factor for periodontal disease. Front. Public Health 2:195. doi: 10.3389/fpubh.2014.00195

This article was submitted to Public Health Education and Promotion, a section of the journal Frontiers in Public Health.

Copyright (c) 2014 Kamath, Mishra and Anand. This is an open-access article distributed under the terms of the Creative Commons Attribution License (CC BY). The use, distribution or reproduction in other forums is permitted, provided the original author(s) or licensor are credited and that the original publication in this journal is cited, in accordance with accepted academic practice. No use, distribution or reproduction is permitted which does not comply with these terms. 